\title{
The effects of Parvovirus B19 infection on pregnant women and fetus
}

\author{
Fügen Yarkın' ${ }^{1}$ Buket Şeflek ${ }^{1}$, Ekrem Sapmaz $^{2}$, Derya Gümürdülü̈ ${ }^{3}$, Fatih Köksal ${ }^{1}$ \\ ${ }^{1}$ Department of Microbiology, Faculty of Medicine, University of Cukurova, Adana, Turkey. \\ ${ }^{2}$ Adana Numune Education and Research Hospital, Adana, Turkey. \\ ${ }^{3}$ Department of Pathology, Faculty of Medicine, University of Cukurova, Adana, Turkey.
}

\begin{abstract}
Background: Human parvovirus B19 infection during pregnancy may cause fetal loss. The aim of this study was to detect the incidence of B19 infection in cases of nonimmune hydrops fetalis (NIHF), spontaneous abortion, intrauterine fetal death (IUFD) and in healthy pregnant women. Material and Methods: Serum samples of pregnant women with NIHF (9), spontaneous abortion (27), IUFD (5) and healthy pregnant women (47) were tested by nested PCR to detect B19 DNA and by ELISA test for B19 specific IgM and IgG antibodies. In other case series of the study, paraffin-embedded fetal and placental tissue samples from 33 NIHF cases and 19 spontaneous abortion cases and placental tissues from 40 normal pregnant women at term were analyzed for B19 DNA by nested PCR. Results: B19 infection was diagnosed by PCR and ELISA tests using serum samples in 4 (44\%) of 9 NIHF cases and 9 (33\%) of 27 spontaneous abortion cases and in $1(20 \%)$ of 5 IUFD cases. In addition, B19 IgG prevalence was found to be $51 \%$ (24/47) in the control group. In other case series, the presence of B19 DNA in fetal and placental tissue samples was found in 14 (42.4\%) of 33 NIHF cases and 6 (31.5\%) of 19 spontaneous abortion cases, while in none of 40 placental tissues samples from the control group. Conclusion: Our findings show that the incidence of parvovirus B19 infection in NIHF and spontaneous abortion cases is relatively high. Nested PCR and ELISA tests should be used together for the early diagnosis of B19 infection in pregnant women.
\end{abstract}

Key words: Parvovirus B19, Pregnancy, Hydrops fetalis, Polymerase chain reaction (PCR), B19 IgM antibody, B19 IgG antibody

\section{Introduction}

Human parvovirus B19 is a small, nonenveloped, singlestranded DNA virus that belongs to the Erythrovirus genus of the Parvoviridae family. Parvovirus B19 infects only humans and shows tropism for erythroid precursor cells. B19 is primarily transmits by respiratory route. Parvovirus B19 infection is associated with various clinical manifestations according to the age, hematological and immunological status of the host. Erythema infectiosum, a childhood rash disease, is the most common clinical manifestation of B19 infection in children. Arthropathy is common in infected patients, especially in women. B19 infections may cause transient aplastic crisis

in patients with hematological disease, chronic anemia in immunocompromised patients, and fetal hydrops and fetal death in the fetus, although infections in immunocompetent patients are generally mild or subclinical (1-4). Fetus may be infected during maternal asymptomatic or symptomatic B19 infection. Most infected infants are asymptomatic. However B19 infection during pregnancy can lead to serious complications such as fetal anemia, spontaneous abortion, non-immune hydrops fetalis (NIHF) and intrauterine fetal death (IUFD) $(1,5,6)$. As many as $30-50 \%$ of pregnant women with B19 infection are asymptomatic or have nonspecific

*Corresponding Author: Fügen Yarkın, Department of Microbiology, Faculty of Medicine, University of Çukurova, Adana 01330, Turkey. E-mail: fugeny @ yahoo.com Received: Oct 01, 2017. Accepted: Oct 23, 2017

This is an Open Access article distributed under the terms of the Creative Commons Attribution Non-Commercial License (http://creativecommons.org/licenses/bync/4.0/) which permits unrestricted non-commercial use, distribution, and reproduction in any medium, provided the original work is properly cited. 
symptoms, so acute B19 infection may be missed without diagnosis. Clinical manifestations related to B19 in pregnant women are arthralgia and rash. Approximately $30-40 \%$ of pregnant women with acute B19 infection have rash. The symptomatic disease usually lasts for a short period (2-5 days). Arthralgia or arthritis occur in $60 \%$ of women. Arthralgia and rash is similar to those of rubella infection. For this reason, the laboratory diagnosis of B19 infection is required for differential diagnosis (7-10).

The aim of this study was to investigate parvovirus B19 infection in pregnant women and to detect the incidence of B19 infection in cases of non-immune hydrops fetalis, spontaneous abortus and intrauterine fetal death by nested PCR and ELISA IgM and IgG antibody tests and thus to show the effect of B19 infection on the fetus.

\section{Material and methods}

To investigate the effect of parvovirus B19 infection on fetus in pregnant women who were admitted to Gynecology Clinic of Adana Numune Education and Research Hospital and Department of Obstetrics and Gynecology, University of Cukurova, Faculty of Medicine, Adana, Turkey, the serum samples obtained from 9 pregnant women with non-immune hydrops fetalis, 27 spontaneous abortus cases and 5 IUFD cases and 47 healthy pregnant women as control group were included in the study. In another case series, parvovirus B19DNA was analyzed in paraffin-embedded fetal and placental tissue samples taken from 33 hydrops fetalis and 19 spontaneous abortus cases. In addition, B19 DNA was investigated in placental tissues of 40 pregnant women with normal term birth.

Parvovirus B19 specific IgM and IgG antibodies were detected by parvovirus B19 IgM ELISA and parvovirus B19 IgG ELISA tests (Focus Diagnostic, USA). The inhouse nested PCR test was used for the detection of B19 $D N A$ in maternal serum and tissue samples (11). Viral DNA extraction from serum samples, paraffin- embedded fetal tissue and placental tissue samples was performed by High Pure Viral Nucleic Acid Kit (Roche Diagnostics, Germany). For B19 DNA detection, in-house nested PCR assay was performed with primers targeting the $369 \mathrm{bp}$ and 284 bp regions in the NS1 gene. The first amplification products were examined by agarose gel electrophoresis for the presence of $369 \mathrm{bp}$ and the second amplification products for $284 \mathrm{bp}$ amplicons (11).

\section{Results}

Women enrolled into the study were between 19 and 35 years of age. In the control group, all the serum samples of 47 healthy pregnant women were $B 19 D N A$ negative, but $24(51 \%)$ were IgG positive, 4 (8.5\%) had acute B19 infection (2 had only IgM, and 2 had both $\operatorname{IgG}$ and $\operatorname{IgM}$ antibodies). B19 seroprevalence was $46 \%(12 / 26)$ in 20 27 years age group and 60\% (9/15) in 28-35 years age group. B19 IgG seropositivity rate in this control group was $51 \%$ and $8.5 \%$ had acute infection, thus the susceptibility rate to B19 infection was $40.5 \%$.

In the case group, total 41 serum samples from 9 women with hydrops fetalis, 27 spontaneous abortus cases and 5 IUFD case were tested by ELISA and PCR tests. Of 9 fetal hydrops cases, B19 infection was detected in 4 (44\%), of which B19 DNA alone (1) or with B19 IgG and IgM antibodies (2) were detected in 3 and only IgG and IgM were positive in 1 serum sample. Among 27 cases of pregnancy terminated by spontaneous abortion, B19 infection was diagnosed in $9(33 \%)$. Of these cases, 6 (22.2\%) had B19 DNA , 2 (7.4\%) had B19 IgG and IgM antibodies, whereas only 1 (3.7\%) had both B19 DNA and $\mathrm{IgM}$ and $\mathrm{IgG}$ antibodies. In IUFD group, only B19 DNA was detected in $1(20 \%)$ of 5 cases (Table 1). These findings show that the importance of B19 in fetal loss cases and also the use of both nested PCR test and B19 ELISA test in the diagnosis of maternal B19 infection.

In the other case series in this study, 14 (42.4\%) of the parafin-embedded samples from 33 hydrops fetalis cases, and $6(31.5 \%)$ of 19 spontaneous abortus samples were B19 DNA positive. B19 DNA was negative in 40 placental tissue samples from the control group.

B19 DNA was found in paraffin-embedded fetal and placental tissues from 33 hydrops fetalis cases, with a maximum of $63.6 \%(21 / 33)$ of lung tissue samples, followed by $57.5 \%$ (19/33) of the placental tissue samples, $48.4 \%(16 / 33)$ of the liver tissue samples and $33.3 \%$ $(11 / 33)$ of the cardiac tissue samples. 
Table 1. Distribution of B19 PCR and ELISA IgM and IgG test results in women with hydrops fetalis, spontaneous abortus and IUFD.

\begin{tabular}{|c|c|c|c|c|c|}
\hline Case groups (n) & $\begin{array}{l}\text { B19 DNA (+) } \\
\text { n (\%) }\end{array}$ & $\begin{array}{l}\text { IgM (+) } \\
\mathbf{n}(\%)\end{array}$ & $\begin{array}{l}\operatorname{IgG}(+) \\
\operatorname{IgM}(+) \\
\mathbf{n}(\%)\end{array}$ & $\begin{array}{l}\text { IgG (+) IgM (+) } \\
\text { B19 DNA (+) } \\
\text { n (\%) }\end{array}$ & $\begin{array}{l}\text { Total } \\
\text { n (\%) }\end{array}$ \\
\hline Hydrops fetalis (9) & $1(11,1)$ & -- & $1(11,1)$ & $2(22,2)$ & $4(44.4)$ \\
\hline Spontaneous abortus (27) & $6(22,2)$ & - - & $2(7,4)$ & $1(3,7)$ & $9(33.3)$ \\
\hline IUFD (5) & $1(20)$ & - - & - - & - - & $1(20)$ \\
\hline
\end{tabular}

\section{Discussion}

Human Parvovirus B19 is a common infection. About 30$50 \%$ of women of childbearing age do not have protective IgG antibodies against B19 and they are susceptible to infection. The highest risk for B19 infection in pregnant women is due to exposure to infected children during epidemic periods. In pregnant women, the incidence of acute B19 infection in endemic periods may be approximately $1-2 \%$, but may exceed $10 \%$ in epidemic periods (12-15).

In the case of maternal B19 infection, virus may be transmitted to the fetus during the viremic phase and the transplacental transmission rate is generally reported to be $30 \%$.Vertical transmission mostly occurs early in the gestation period when placental trophoblasts have a high expression of the $\mathrm{P}$ antigen, the cellular receptor for B19. Most fetal B19 infections are asymptomatic and healthy babies are born. However, B19 infection may result in spontaneous abortion in the first trimester, fetal hydrops in the second trimester and IUFD in the second and third trimester. Fetal complications usually occur 3-6 weeks after maternal infection, but may be as late as 18 weeks. The incidence of fetal loss due to B19 infection during pregnancy is about $10 \%(6,7,12)$.

Although fetal loss due to intrauterine B19 infection may occur at any time during pregnancy, most cases have been reported between 11 and 22 weeks of gestation, at the period of the highest hematopoietic activity in fetal liver. High fetal sensitivity to B19 infection is due to immature immune response, and more importantly, shortened erythrocyte life span (50-75 days) in fetus, whereas it is
100-120 days in adults, and increased amount of erythrocytes (3-4 times higher). The lysis of erythroid progenitor cells in infected fetus can lead to cease of erythropoiesis and serious anemia develops. Heart failure due to severe anemia, viral myocarditis and hepatic dysfunction may lead to fetal hydrops $(5,6,16)$. The risk of developing NIHF due to the B19 virus has been reported to be $3.9 \%$ throughout the entire pregnancy, with the highest risk being $7.1 \%$ when the infection occurs between 13-20 weeks gestation. It has been reported that 5-20\% of all NIHF cases are caused by B19 (5,6,17-19).

Among the studies investigating the association between fetal hydrops and B19 virus, in Brazil, Da Silva and colleagues found B19 IgM and IgG antibodies in 4 (23.5\%) of 17 fetal hydrops cases. Anti-parvovirus B19 IgG antibodies were detected in $71 \%$ of 249 pregnant women (20).

In Ergunay et al.'s study, B19 DNA was detected in 2 (9.1\%) placental and liver tissues samples of $22 \mathrm{NIHF}$ cases by real time PCR (21).

In our study, of 9 NIHF cases, 4 (44\%) was found to have B19 infection by testing serum samples using ELISA and PCR tests. B19 DNA alone (1) or with B19 IgG and IgM antibodies (2) in 3 (33\%) and both IgG and IgM antibodies were positive only in 1 (11\%) of 4 serum samples. These findings clearly demonstrate the necessity of using both tests. When fetal complications occur, maternal B19 IgM antibodies may fall below detectable levels. On the other hand, PCR negative, IgM positive result indicates that the virus is rapidly cleared from the maternal blood due to 
antibodies. Da Silva found B19 IgM and IgG in $23.5 \%$ of maternal sera of the NIHF cases (20). Both IgG and IgM positivity was $33 \%$ (3) in our study.

In our study, B19 DNA was found in none of the 40 placental tissues of normal pregnancies (control group). B19 DNA was positive in fetal and placental tissue specimens from 14 (42.4\%) of 33 NIHF cases retrospectively analyzed by nested PCR. The rate of $B 19$ $D N A$ in NIHF cases is quite high $(42.4 \%)$ and it is similar to the incidence (40\%) in NIHF cases reported by Carlsen et al (22). The rates of NIHF cases related to B19 virus found by other investigators using PCR test ranged from $5.9-19.1 \%(19,21,23-26)$.

In paraffin-embedded fetal and placental tissues from 33 hydrops fetalis cases, lung tissue samples were found to demonstrate the highest rate of B19 DNA (63.6\%) followed by placental tissue (57.5\%), liver tissue (48.4\%) and cardiac tissue samples $(33.3 \%)$, respectively. The selection of a fetal lung tissue specimen is particularly appropriate for $B 19 D N A$ detection.

In studies investigating the relationship B19 and spontaneous abortus, Salakawy et al. detected B19 DNA by nested PCR in 31.6\% (19/60) of fetal and placental tissues of unexplained abortions in the first trimester and $6.67 \%$ of placental samples of control group (27).

El-sayed Zaki reported that B19 IgM antibodies were positive in $84 \%$ and $B 19 D N A$ in $48 \%$ of pregnant women with recurrent spontaneous abortion (28). The rate of antiB19 IgM antibody found by Kishore in 116 pregnant women with unknown recurrent spontaneous abortion was $19.8 \%$ (29). In the study by Tolfvenstam, B19 DNA was detected in $5 \%$ of 37 spontaneous abortus cases $(<22$ gestation week), but in none of 29 cases of induced abortion cases (30).

In our study, $6(31.5 \%)$ of 19 spontaneous abortus cases were found to have B19DNA, which is similar to result $(31.6 \%)$ of Salakwy, but lower than the rate $(48 \%)$ detected by El-sayed Zaki $(27,28)$. In other studies conducted in China, the incidence of B19 in spontaneous abortus cases has been reported between $24.5 \%$ and $29.3 \%$ (31-33). Tolfvenstam reported lower rate (5\%) of $B 19$ DNA (30).

In our study, B19 infection was diagnosed in 9 (33\%) of maternal serum samples from 27 spontaneous abortus cases. This rate (33\%) is compatible with the rate of $B 19$ $D N A$ positivity $(31.5 \%)$ found in the other case series in this study and the incidence of B19 in spontaneous abortus cases seems to be quite high. IgG and IgM was detected in 2 (7.4\%) out of 9 cases of B19 infection, while B19 DNA alone was positive in $6(22.2 \%)$ and with $\mathrm{B} 19 \mathrm{IgG}$ and $\mathrm{B} 19$ IgM was positive in $1(3.7 \%)$ of 7 cases. These findings show that only 3 of the samples $(11 \%)$ were positive by B19 IgG and IgM antibody test, whereas only 7 (25.9\%) by PCR test were positive and both tests were complementary for the correct diagnosis of B19.

Tolfvenstam et al. investigated B19 DNA in placental and fetal tissues of 47 cases of IUFD observed during 2 nd and 3rd trimester of pregnancy and 7 of 47 cases (15\%) were found to be positive for B19DNA. All but one of the DNApositive cases of IUFD were non-hydropic. It has been reported that the frequency of B19DNA in fetal death cases of late second trimester and third trimester is quite high (30). In Sweden, Skjoldebrand-Sparre et al. found B19 DNA in 7 (7.5\%) of the placental tissues of 93 IUFD cases and none of the cases were hydropic (34). In the study of Petersson et al., parvovirus B19 DNA was detected in $2(3.8 \%)$ of 52 IUFD cases, whereas in none of the placental biopsies from normal pregnancies at term, as control samples (35). In our study, B19 DNA was detected in $1(20 \%)$ of 5 cases, which was higher than the rates reported by Tolfvenstaml (15\%), Skjoldebrand-Sparre (7.5\%) and Petersson (3.8\%). However, the number of cases (5) in our series is rather low $(30,34,35)$.

In our study, $51 \%(24 / 47)$ of normal pregnant women in the control group were positive for B19 IgG antibodies. B19 seroprevalence increased with age progression, from $46 \%$ in 20-27 years age group to $60 \%$ in $28-35$ years age group. None of the healthy pregnant women had $B 19$ DNA.

In studies on the seroprevalence of B19 in pregnant women, in Argentina, Pedranti detected 66\% (36). In South Western Finland, Alanen reported that the seroprevalence of B19 was $58.6 \%$ and the mean age of seropositive women was 29.7 years (37). Enders found that the prevalence of B19 IgG in pregnant women in Germany was $69.2 \%$, and in the Netherlands, Van Gessel reported $70 \%(38,39)$. In Denmark, Jensen found that seroprevalence of $\mathrm{B} 19 \mathrm{IgG}$ was $66 \%$ and the rate of acute B19 infection was 10.3\% (40). In England, Vyse reported that susceptibility rates to B19 in women were $36.3 \%$ between $15-19$ years, $34.4 \%$ between $20-24$ years, $42.1 \%$ between 25-29 years and 38.8\% between 30-34 years of 
age (41). Mossong reported that the susceptibility rates for pregnant women in Europe were $39.9 \%$ in Italy, $26 \%$ in Belgium, 38\% in England, 43.5\% in Finland and 36.8\% in Poland, and the risk for B19 infection in pregnant women was $0.61-1.58 \%$ (42). In our study, B19 seroprevalence was $51 \%$ in healthy pregnant women and $8.5 \%$ had acute infection, thus the susceptibility rate to B19 infection was $40.5 \%$.

\section{Conclusion}

In conclusion, the presence of parvovirus B19 DNA in $42.4 \%$ of 33 fetal and placental tissues of NIHF cases and $31.5 \%$ of 19 spontaneous abortion cases by nested PCR test revealed that a relatively high rate of hydrops fetalis and spontaneous abortus cases were associated with parvovirus B19. The use of nested PCR and ELISA IgM and $\operatorname{IgG}$ antibody tests for the early diagnosis of parvovirus B19 infection in pregnant women is necessary, as timely treatment with intrauterine blood transfusion would increase the fetal survival rate in cases with hydrops fetalis caused by parvovirus.

\section{Ethics Committee Approval: NA Informed Consent: NA}

Peer-review: Externally peer-reviewed.

Conflict of Interest: No conflict of interest was declared by the author.

Financial Disclosure: The author declared that this study has received no financial support.

\section{References}

1. Rogo LD, Mokhtari-Azad T, Kabir MH, Rezaei F. Human parvovirus B19: a review. Acta Virol. 2014;58(3):199-213.

2. Servant-Delmas A, Lefrère JJ, Morinet F, Pillet S. Advances in human B19 erythrovirus biology. J Virol. 2010;84(19):96589665.

3. Rogo LD, Mokhtari-Azad T, Kabir MH, Rezaei F.Human parvovirus B19: a review. Acta Virol. 2014;58(3):199-213.

4. Broliden K, Tolfvenstam T, Norbeck O. Clinical aspects of parvovirus B19 infection. J Intern Med. 2006;260(4):285-304.

5. Giorgio E, De Oronzo MA, Iozza I, Di Natale A, Cianci S, Garofalo G, Giacobbe AM, Politi S. Parvovirus B19 during pregnancy: a review. J Prenat Med. 2010;4(4):63-66.

6. Ornoy A, Ergaz Z.Parvovirus B19 infection during pregnancy and risks to the fetus.Birth Defects Res. 2017;109(5):311-323.

7. Servey JT, Reamy BV, Hodge J. Clinical presentations of parvovirus B19 infection. Am Fam Physician. 2007;75(3):373376.

8. Chisaka H, Ito K, Niikura H, Sugawara J, Takano T, Murakami T, Terada Y, Okamura K, Shiroishi H, Sugamura K, Yaegashi N. Clinical manifestations and outcomes of parvovirus B19 infection during pregnancy in Japan. Tohoku J Exp Med.
2006;209(4):277-283.

9. Enders M, Weidner A, Enders G.Current epidemiological aspects of human parvovirus B19 infection during pregnancy and childhood in the western part of Germany. Epidemiol Infect. 2007;135(4):563-569.

10. Zavattoni M, Paolucci S, Sarasini A, Tassis B, Rustico M, Quarenghi A, Piralla A, Baldanti F. Diagnostic and prognostic value of molecular and serological investigation of human parvovirus B19 infection during pregnancy. New Microbiol. 2016;39(3):181-185.

11. Broliden K, Tolfvenstam T, Ohlsson S, Henter JI. Persistent B19 parvovirus infection in pediatric malignancies. Med Pediatr Oncol. 1998;31(2):66-72.

12. 12- de Jong EP, Walther FJ, Kroes AC, Oepkes D. Parvovirus B19 infection in pregnancy: new insights and management. Prenat Diagn. 2011;31(5):419-425.

13. Lamont RF, Sobel JD, Vaisbuch E, Kusanovic JP, MazakiTovi S, Kim SK, Uldbjerg N, Romero R. Parvovirus B19 infection in human pregnancy. BJOG. 2011;118(2):175-186.

14. Staroselsky A, Klieger-Grossmann C, Garcia-Bournissen F, Koren G. Exposure to fifth disease in pregnancy. Can Fam Physician. 2009;55(12):1195-1198.

15. Tolfvenstam T, Broliden K. Parvovirus B19 infection. Semin Fetal Neonatal Med. 2009;14(4):218-221.

16. Chisaka H, Morita E, Yaegashi N, Sugamura K. Parvovirus B19 and the pathogenesis of anaemia. Rev Med Virol. 2003;13(6):347-359.

17. Landry ML. Parvovirus B19. Microbiol Spectr. 2016 Jun; 4(3). doi:10.1128/microbiolspec.

18. Enders M, Weidner A, Zoellner I, Searle K, Enders G. Fetal morbidity and mortality after acute human parvovirus B19 infection in pregnancy: prospective evaluation of 1018 cases. Prenat Diagn. 2004;24(7):513-518.

19. Yaegashi N, Niinuma $T$, Chisaka H, Watanabe T, Uehara S, Okamura K, Moffatt S, Sugamura K, Yajima A. The incidence of, and factors leading to, parvovirus B19-related hydrops fetalis following maternal infection; report of 10 cases and metaanalysis. J Infect. 1998;37(1):28-35.

20. Da Silva AR, Nogueira SA, Alzeguir JC, da Costa MC, do Nascimento JP. Anti-parvovirus B19 IgG antibody prevalence in pregnant women during antenatal follow-up and cases of nonimmune hydropsis fetalis due to parvovirus B19, in the City of Rio de Janeiro. Rev Soc Bras Med Trop. 2006;39(5):467-472.

21. Ergunay K, Altinok G, Gurel B, Pinar A, Sungur A, Balci $\mathrm{S}$, Ustacelebi S. Identifying the etiologic role of Parvovirus B19 in non-immune hydrops fetalis by histopathology, immunohistochemistry and nucleic acid testing: a retrospective study. Central European Journal of Medicine. 2007;2(3):271279.

22. Carlsen KM.Human parvovirus B19 erythrovirus. Methods established for virological and diagnostic aspects. APMIS Suppl. 2006;(120):1-121.

23. Quemelo PR, Lima DM, da Fonseca BA, Peres LC. Detection of parvovirus B19 infection in formalin-fixed and paraffin-embedded placenta and fetal tissues. Rev Inst Med Trop Sao Paulo. 2007;49(2):103-107.

24. Landolsi H, Yacoubi MT, Bouslama L, Lahmar A, Trabelsi A, Hmissa S, et al. Detection of the human Parvovirus B19 in nonimmune hydrops fetalis using immunohistochemistry and 
nested-PCR in formalin-fixed and paraffin-embedded placenta and fetal tissues. Pathol Biol (Paris). 2009 May;57(3):e1-7.

25. Jordan JA. Identification of human Parvovirus B19 infection in idiopathic nonimmune hydrops fetalis. Am J Obstet Gynecol 1996;174(1 Pt 1):37-42.

26. Mark Y, Rogers BB, Oyer CE. Diagnosis and incidence of fetal parvovirus infection in an autopsy series: II. DNA Amplification. J. Pediatr. Pathol. 1993; 13: 381-386.

27. Salakawy A., Mohammed N, Shaker O. Human Parvovirus B19, Cytomegalovirus Infections and Thyroid Autoimmunity in Women with Recurrent First Trimester Abortion. The Egyption Journel Of Hospital Medicine 2000;1:33-47.

28. El-Sayed Zaki M, Goda H. Relevance of parvovirus B19, herpes simplex virus 2 , and cytomegalovirus virologic markers in maternal serum for diagnosis of unexplained recurrent abortions. Arch Pathol Lab Med. 2007;131(6):956-960.

29. Kishore J, Gupta I. Serological study of parvovirus B19 infection in women with recurrent spontaneous abortions. Indian J Pathol Microbiol. 2006;49(4):548-550.

30. Tolfvenstam T, Papadogiannakis N, Norbeck O, Petersson K, Broliden K. Frequency of human parvovirus B19 infection in intrauterine fetal death. Lancet. 2001;357(9267):1494-1497.

31. Wang R, Chen $X$, Han M. Relationship between human parvovirus B19 infection and spontaneous abortion. Zhonghua Fu Chan Ke Za Zhi. 1997;32(9):541-543.

32. $\mathrm{Xu} \mathrm{D}$, Zhang G, Wang R. The study on detection of human Parvovirus B19 DNA in spontaneous abortion tissues. Zhonghua Shi Yan He Lin Chuang Bing Du Xue Za Zhi.1998;12(2):158160.

33. Xu D, Zhang G, Li B, Wang X, Sun X. Relationship between human parvovirus B19 infection and spontaneous abortion and congenital heart disease in China. Zhonghua Fu Chan Ke Za Zhi. 2002;37(6):324-326.

34. Skjöldebrand-Sparre L, Tolfvenstam T, Papadogiannakis N, Wahren B, Broliden K, Nyman M. Parvovirus B19 infection: association with third-trimester intrauterine fetal death. BJOG. 2000;107(4):476-480.

35. Petersson K, Norbeck O, Westgren M, Broliden K. Detection of parvovirus B19, cytomegalovirus and enterovirus infections in cases of intrauterine fetal death. $\mathbf{J}$ Perinat Med. 2004;32(6):516-521.

36. Pedranti MS, Adamo MP, Macedo R, Zapata MT. Prevalence of anti-rubella and anti-parvovirus B19 antibodies in pregnant women in the city of Córdoba, and in women of fertile age in the city of Villa Mercedes, province of San Luis. Rev Argent Microbiol. 2007;39(1):47-50.

37. Alanen A, Kahala K, Vahlberg T, Koskela P, Vainionpää R. Seroprevalence, incidence of prenatal infections and reliability of maternal history of varicella zoster virus, cytomegalovirus, herpes simplex virus and parvovirus B19 infection in SouthWestern Finland. BJOG. 2005;112(1):50-56.

38. Enders M, Weidner A, Enders G. Current epidemiological aspects of human parvovirus B19 infection during pregnancy and childhood in the western part of Germany. Epidemiol Infect. 2007;135(4):563-569.

39. Van Gessel PH, Gaytant MA, Vossen AC, Galama JM, Ursem NT, Steegers EA, et al. Incidence of parvovirus B19 infection among an unselected population of pregnant women in the Netherlands: A prospective study. Eur J Obstet Gynecol
Reprod Biol. 2006;128(1-2):46-49.

40. Jensen IP, Thorsen P, Jeune B, Møller BR, Vestergaard BF. An epidemic of parvovirus B19 in a population of 3,596 pregnant women: a study of sociodemographic and medical risk factors. BJOG. 2000;107(5):637-643.

41. Vyse AJ, Andrews NJ, Hesketh LM, Pebody R. The burden of parvovirus B19 infection in women of childbearing age in England and Wales. Epidemiol Infect. 2007;135(8):1354-1362. 42. Mossong J, Hens N, Friederichs V, Davidkin I, Broman M, Litwinska B, et el. Parvovirus B19 infection in five European countries: seroepidemiology, force of infection and maternal risk of infection. Epidemiol Infect. 2008;136(8):1059-1068.

Submit your next manuscript to the JICM and take full advantage of:

- Convenient online submission,

- Thorough peer review, Fast Response,

- No charges,

- Immediate publication on acceptance,

- Inclusion in Scopemed and High quality indexes,

- Research which is freely available for redistribution of the worldwide literature

To submit your manuscript, click on $h t t p: / / w w w . j i a c m . c o m$

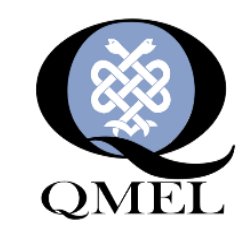

Medicine \& Publishing

Published by The ${ }^{\circledR}$ QMEL.org

Medicine \& Education \& Library

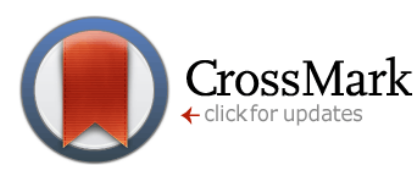

